\title{
Physicochemical and Bacteriological Qualities of Otamiri River Water and Sediment in South Eastern Nigeria
}

\author{
Okechi Reuben Nwoye ${ }^{1, ~ *, ~ C h u k w u r a ~ E d n a ~ I f e o m a ~}{ }^{2}$ \\ ${ }^{1}$ Department of Biotechnology, Federal University of Technology, Owerri, Nigeria \\ ${ }^{2}$ Department of Applied Microbiology and Brewing, Nnamdi Azikiwe University, Awka, Nigeria
}

Email address:

popebenn@yahoo.com (Okechi R. N.), ednaify@hotmail.com (Chukwura E. I.)

${ }^{*}$ Corresponding author

\section{To cite this article:}

Okechi Reuben Nwoye, Chukwura Edna Ifeoma. Physicochemical and Bacteriological Qualities of Otamiri River Water and Sediment in South Eastern Nigeria. Frontiers in Environmental Microbiology. Vol. 6, No. 2, 2020, pp. 18-26. doi: 10.11648/j.fem.20200602.12

Received: May 16, 2020; Accepted: May 28, 2020; Published: June 4, 2020

\begin{abstract}
The bacteriological, physicochemical and anionic surfactants qualities of Otamiri river water and sediment were analysed, using standard techniques. The bacteriological analyses revealed the presence of Serratia marcescens (SerEW01) (33.33\%), Staphylococcus (22.20\%), Streptococcus $(22.20 \%)$, Enterobacter $(11.11 \%)$, Escherichia coli $(11.11 \%)$ in Otamiri river water as well as Acinetobacter seifertii (42.10\%), Bacillus (15.80\%), Escherichia coli (15.80\%), Klebsiella (10.53\%) and Streptococcus species (5.30\%), in the sediment. Some of these bacteria are indicators of fecal contamination of the river water. Iron recorded the highest value among the heavy metals $(1.972 \mathrm{mg} / \mathrm{l})$, in the river water while Co was not detected. Also, $\mathrm{Pb}$, $\mathrm{Cd}, \mathrm{Ni}, \mathrm{Hg}$, electrical conductivity and turbidity recorded values higher than WHO standards for drinking water. In the sediment, $\mathrm{Fe}$ and $\mathrm{Cd}$ had the highest and least values 19.82 and $0.025 \mathrm{mg} / \mathrm{kg}$ respectively. The $\mathrm{pH}$ of the river and sediment were 6.42 and 5.40. Similarly, among the anionic surfactants, sodium dodecyl sulfate (SDS) was the highest in both Otamiri river water $(0.100 \mathrm{mg} / \mathrm{l})$ and sediment $(0.453 \mathrm{mg} / \mathrm{kg})$, while perfluorobutane sulfate was not detected in the river water. These results imply that the quality of Otamiri river water and possibly the sediment are below the WHO recommendations for drinking water. People using the river water for drinking and other domestic activities should therefore purify it adequately to avert possible health hazards.
\end{abstract}

Keywords: Heavy Metals, Otamiri River and Sediment, Anionic Surfactants, SDS

\section{Introduction}

Water is one of the basic necessities needed for the survival and sustenance of all living organisms on earth. Water is required for various purposes like drinking and other domestic needs, agriculture, power generation, navigation, as well as for industrial and recreation activities $[1,2]$. Although municipal purposes may remain the largest water requirement, the quality requirements for these purposes differ from those required for industrial and commercial purposes [3]. Water quality deals with the physicochemical and biological characteristics of water with regards to its suitability for a particular need [4]. Clean and fresh water is necessary for domestic activities, swimming and food processing, as well. River pollution is the change in the quality of river water which could be directly or indirectly attributed to human activities, thus making it unfit for any or all the purposes it would have been suitable for in its unpolluted state. River pollution could lead to some undesirable effects such as contamination of water supplies, restriction of its use for recreational activates, loss of aquatic lives, creation of nuisances, as well as hindrances to navigation [5]. Water bodies however have the capacity to assimilate limited amount of pollution without serious deleterious effects due to dilution and self purification capacities [6].

Otamiri river is one of the major rivers that pass through Owerri urban and environs. This river serves as a source of aquatic foods and water for domestic activities, urban agriculture as well as for other purposes. All the 
drainages in Owerri urban and environs discharge untreated wastewater into the river or its tributary. Nekede mechanic village, hospitals, car washing and laundry outfits are located along the banks of the river. When it rains, run-offs from Owerri urban and environs gain unrestricted access into the river. Similarly, in addition to sand mining activities that go on in the river, solid wastes are also dumped and incinerated at the river bank. These waste dumps could contain a wide variety of chemical substances that leach into the river. This study is therefore aimed at determining the bacteriological and physicochemical qualities of Otamiri river water and its sediment.

\section{Materials and Methods}

\subsection{Study Area}

Otamiri River is one of the two major surface waters that traverse the Owerri city (Figure 1). This river runs south from its source at Egbu through Owerri, Nekede, Ihiagwa, among others and finally to Etche, Rivers State of Nigeria, from where it finally joins the Atlantic Ocean. The Otamiri watershed which covers about 10,000 square kilometers, is mostly covered by depleted rain forest vegetation, with an annual rainfall of $2,250-2,500 \mathrm{~mm}$ and mean annual temperature of $27^{\circ} \mathrm{C}[7]$.
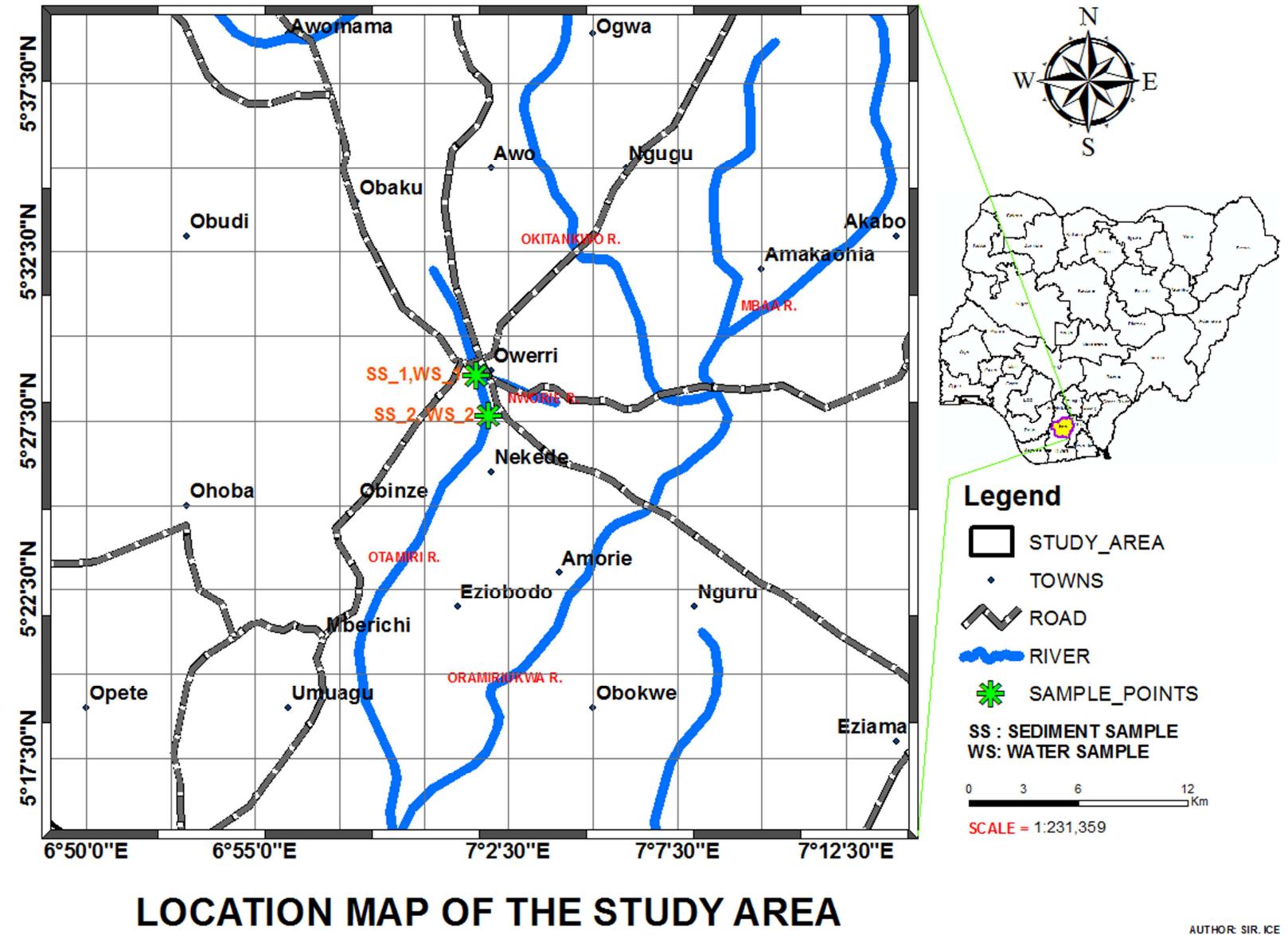

Figure 1. Location Map of the Study Area, Showing Sampled Points (in Green).

\subsection{Samples Collection}

Both water and sediment samples were collected along the course of the river, adjacent the mechanic village, Nekede. The first sample was collected approximately 100 meters downstream of the point Nworie river joined Otamiri River $(5.465 \mathrm{~N}, 7.035 \mathrm{E})$, while the second sample was collected 100 meters downstream of the first location $(5.463 \mathrm{~N}, 7.034 \mathrm{E})$. The samples were collected as described by Nweke et al. [8]. Sediment samples were collected with Eckman grab sampler, and were later pooled together to form composite sample in a clean cellophane bag. The water samples which were collected with sterile $750 \mathrm{ml}$ plastic cans were also pooled together in 1.5 liter sterile plastic container. The plastic containers were previously sterilized by soaking for 30 minutes in 95\% ethanol and rinsed severally with sterile water. All the samples were taken to the laboratories for analysis. The water samples were preserved in the refrigerator at $4^{\circ} \mathrm{C}$, until required.

\subsection{Bacteriological Analysis of the Samples}

One gram (1g) of the sediment sample was suspended in 9 $\mathrm{ml}$ of sterile water contained in a 100-ml Erlenmeyer flask and shook vigorously for 60 seconds and allowed to stand for about 10 minutes [9]. Ten-fold serial dilutions of sediment 
and water samples were then carried out. Then $0.1 \mathrm{ml}$ of $10^{-5}$ dilution of sediment and $10^{-3}$ dilution of the water sample were aseptically inoculated onto sterile nutrient agar plates in duplicates, using sterile Pasteur pipette and then spread with sterile glass rod and incubated for 24 hours at $37^{\circ} \mathrm{C}$. The bacteria colonies were then counted to determine total heterotrophic counts of the samples, from where the percentage occurrence of the isolates was obtained. Discrete colonies were further subcultured on Nutrient agar plates to obtain pure cultures, which were then stored on agar slants in the refrigerator at $4^{\circ} \mathrm{C}$. The isolates obtained were identified using morphological characteristics, Gram staining, spore staining and biochemical tests [10].

\subsection{Physicochemical Analysis of the Water Sample}

Parameters selected for analyses include temperature, $\mathrm{pH}$, electrical conductivity, total hardness, turbidity, chloride, phosphate, biochemical oxygen demand (BOD) and dissolved oxygen (DO). Digital Labtech $\mathrm{pH}$ meter, Jenway (Model: HANNA 1910) was used to determine $\mathrm{pH}$ and temperature, while HANNA EC 215 conductivity meter was used to determine conductivity $\mathrm{HACH}$ spectrophotometer was used to determine turbidity at wavelength of $860 \mathrm{~nm}$ and programme number 750. DO was determined using EXTECH digital Dissolved Oxygen meter Model DO 700 and $\mathrm{BOD}_{5}$ was determined using $\mathrm{DO}$ meter. Phosphate was determined as described by US-EPA [11], while Chloride was by estimation in accordance with Argentometric method as described by APHA [12].

\subsection{Physiochemical Analyses of Sediment Sample}

The sediment sample was taken to the laboratory and air dried, clumps crushed with porcelain mortar and sieved with $2 \mathrm{~mm}$ stainless metallic sieve.

Sediment $\mathrm{pH}$ was determined as described by Hendershot et al. [13], while phosphate was determined according to the method of Fawole and Oso [9].

\subsection{Heavy Metal Analysis of Water and Sediment Samples}

Heavy metal analysis was carried out using Agilent FS240AA Atomic Absorption Spectrophotometer according to the method of APHA [12]. Sediment sample digestion was carried out according to Adrian [14] Two grams (2 g) of the dried sample was weighed into a digestion flask, followed by the addition of $20 \mathrm{ml}$ of the acid mixture $(650 \mathrm{ml}$ concentrated $\mathrm{HNO}_{3} ; 80 \mathrm{ml}$ perchloric acid; $20 \mathrm{ml}$ concentrated $\mathrm{H}_{2} \mathrm{SO}_{4}$ ). The mixture was then heated till a clear digest was obtained. The digest was then diluted with distilled water up to the $100 \mathrm{ml}$ mark. River water sample was digested according to the method by Adrian [14]. The sample was shaken thoroughly to mix well. A $100 \mathrm{ml}$ of it was transferred into a 250-ml glass beaker, into which $5 \mathrm{ml}$ of concentrated nitric acid was added and then heated to boil until the volume decreased to about $20 \mathrm{ml}$, by incrementally adding $5 \mathrm{ml}$ of concentrated nitric acid until all the residue was totally dissolved. The mixture was allowed to cool and transferred into a $100 \mathrm{ml}$ volumetric flask and consequently made up to $100 \mathrm{ml}$ using deionized distilled water. The sample was aspirated into the oxidizing air-acetylene flame. On aspiration of the aqueous sample, the sensitivity for $1 \%$ absorption was noted. The digested samples were then analyzed for $\mathrm{Co}, \mathrm{Fe}, \mathrm{Cu}, \mathrm{Pb}, \mathrm{Cd}, \mathrm{Zn}, \mathrm{Ni}$ and $\mathrm{Hg}$ at their respective wavelength, using atomic absorption spectrophotometer.

\subsection{Determination of Anionic Surfactants in the Samples}

Soxhlet extraction method was used in accordance with AOAC [15]. Ten grams $(10 \mathrm{~g})$ of the homogenized sample was mixed with $20 \mathrm{~g}$ of anhydrous sodium sulphate in agitate mortar to absorb moisture. The homogenate was then placed in extraction cellulose thimble $(33.94 \mathrm{~mm})$, covered with a Whatman filter paper and inserted into a Soxhlet extraction chamber of the Soxhlet unit. Extraction was carried out with $200 \mathrm{ml}$ ethanol for 3 hours. The crude extract obtained was evaporated using a rotary vacuum evaporator at $40^{\circ} \mathrm{C}$, just to dryness.

Florisil was heated over night (Ca. 15h) in an oven at $130^{\circ} \mathrm{C}$, transferred to a $250 \mathrm{ml}$ beaker and placed in a desiccator. Onto a $1.0 \mathrm{~g}$ of activated florisil (60-100 nm mesh) on an $8 \mathrm{ml}$ column plugged with glass wool, $0.5 \mathrm{~g}$ anhydrous $\mathrm{Na}_{2} \mathrm{SO}_{4}$ was added. The packed column was conditioned by filling it with $5 \mathrm{ml}$ of $\mathrm{n}$-hexane. The stopcock was thereafter opened to allow $n$ - hexane run out until it just reaches the top of sodium sulphate in a receiving vessel whilst tapping the top of the column gently until the florisil settles well in the column. Disposable Pasteur pipette was used in transferring the extract to the column from an evaporating flask. A $1 \mathrm{ml}$ portion of $n$-hexane was used to rinse each evaporating flask twice and these were also added to the column. The eluate was collected into an evaporating flask and evaporated to dryness using rotary evaporator. The dry eluate was then dissolved in $1 \mathrm{ml}$ n-hexane and analyzed using Gas Chromatography. For the river water sample, a portion of the water sample was mixed with equal volume of n-hexane and shook very well before transferring to a separating funnel, where it forms two layers. The water layer was remove, while the n-hexane layer was collected, concentrated by evaporation and then analyzed, using Gas Chromatography.

\section{Results}

The results of the physicochemical parameters analysis of Otamiri river and sediment are shown in Table 1. From the results, the $\mathrm{pH}$ and temperature of the river water were 6.42 and $26.1{ }^{\circ} \mathrm{C}$, while the sediment recorded $\mathrm{pH}$ of 5.40 . The results of heavy metal analyses showed that, iron, zinc and mercury recorded the highest values; 19.818, 16.548 and $3.678 \mathrm{mg} / \mathrm{l}$ in sediment and 1.972, 1.556 and $1.329 \mathrm{mg} / 1$ in river water sample respectively. Cadmium recorded the least value $(0.025 \mathrm{mg} / \mathrm{l})$ in sediment while cobalt was not detected in the river water sample. Conductivity was high in the water sample $(115.8 \mathrm{us} / \mathrm{cm})$, while total hardness was $0.32 \mathrm{mg} / \mathrm{l}$ and turbidity $22.8 \mathrm{NTU}$. Among the anionic surfactants, sodium 
dodecyl sulfate (SDS) recorded the highest values in river water $(0.100 \mathrm{mg} / \mathrm{l})$ and sediment $(0.453 \mathrm{mg} / \mathrm{kg})$, while Perfluorobutanesulfate was not detected in the river water. Sodium lauryl sulfate recorded the least value in the sediment sample $(0.0018 \mathrm{mg} / \mathrm{mg})$.

The results of the biochemical characteristics and percentage occurrence of the bacterial isolates from the Otamiri river and sediment are shown in Table 2. Five different bacterial genera were isolated from the river water, with Serratia marcescens (SerEW01) (33.33\%) recording the highest percentage occurrence while Enterobacter and Escherichia coli recorded the least (11.11\%). In sediment sample, six bacterial genera were isolated, with Acinetobacter seifertii recording the highest percentage occurrence $(42.10 \%)$, and Streptococcus species recording the least (5.30\%).

Table 1. Physicochemical Properties of Otamiri River and Sediment Samples.

\begin{tabular}{llll}
\hline Parameter & $\begin{array}{l}\text { Sediment } \\
(\mathbf{m g} / \mathbf{k g})\end{array}$ & $\begin{array}{l}\text { River } \\
(\mathbf{m g} / \mathbf{l})\end{array}$ & $\begin{array}{l}\text { WHO Standard } \\
\text { (Water) }\end{array}$ \\
\hline Cobalt & 0.163 & 0.000 & No guideline \\
Iron & 19.818 & 1.972 & No guideline \\
Copper & 0.969 & 0.059 & $2 \mathrm{mg} / 1$ \\
Lead & 2.383 & 0.546 & $0.01 \mathrm{mg} / 1$ \\
Cadmium & 0.025 & 0.093 & $0.003 \mathrm{mg} / 1$ \\
Zinc & 16.548 & 1.556 & $3 \mathrm{mg} / 1$ \\
Nickel & 1.054 & 0.066 & $0.02 \mathrm{mg} / 1$ \\
Mercury & 3.678 & 1.329 & $0.001 \mathrm{mg} / 1$ \\
pH & 5.40 & 6.42 & $6.5-8.5$ \\
Phosphate & 18.41 & 0.032 & 3.5 \\
Temperature & & 26.1 & None \\
Conductivity $(\mu \mathrm{S} / \mathrm{cm})$ & & 115.8 & 100 \\
Total hardness & & 0.32 & 500 \\
Turbidity (NTU) & & 22.8 & 5.0 \\
Chloride & & 1.08 & $250 \mathrm{mg} / 1$ \\
BOD & & 5.0 & 5.0 \\
DO & & 9.8 & 10 \\
Perfluorobutanesulfate & 0.0142 & 0.000 & \\
Sodium methyl sulfate & 0.0532 & 0.060 & \\
Ammonium lauryl sulfate & 0.0303 & 0.070 & \\
Sodium dodecyl sulfate & 0.4531 & 0.100 & \\
Sodium lauretth sulfate & 0.0018 & 0.070 & \\
\hline
\end{tabular}

Table 2. Bacterial Isolates from Otamiri river water and sediment and their\% Occurrence.

\begin{tabular}{ll}
\hline Sample/Bacteria & \% Occurrence \\
\hline River water & \\
Staphylococcus & 22 \\
Enterobacter & 11.11 \\
Serratia marcescens (SerEW01) & 33.33 \\
Streptococcus & 22.22 \\
Escherichia coli & 11.11 \\
Sediment & \\
Streptococcus & 5.30 \\
Pseudomonas & 10.53 \\
Klebsiella & 10.53 \\
Acinetobacter seifertii & 42.10 \\
Bacillus & 15.80 \\
Escherichia coli & 15.80 \\
\hline
\end{tabular}

\section{Discussion}

The $\mathrm{pH}$ of surface waters is vital to aquatic life because of its effects on the ability of aquatic organisms to regulate basic life-sustaining processes, most importantly respiratory activities and exchange of salts with their surrounding [16]. Similarly, the $\mathrm{pH}$ of a water body is also known to affect the dissolved oxygen level in such water. The $\mathrm{pH}$ of Otamiri river water was 6.42 , while that of the sediment was 5.40 . The $\mathrm{pH}$ of both the river water and sediment were slightly acidic, with the sediment being more acidic. The $\mathrm{pH}$ of the river water was however within the WHO recommended range for drinking water. In addition, $\mathrm{pH}$ range of 6.45-7.56 has been reported for Otamiri river by previous authors [17, 5, 18]. Although $\mathrm{pH}$ ranges of 6.31-6.60 and 6.30-6.50 have been reported for Otamiri sediment for dry and rainy seasons respectively [19], the $\mathrm{pH}$ of 5.40 recorded for Otamiri sediment in this study was moderately acidic. This could be attributed to increasing pollution of the river through dumping of untreated wastes and leachates from solid wastes [17].

The temperature of the river was $26.1^{\circ} \mathrm{C}$, this is below the WHO recommended range of $27-28^{\circ} \mathrm{C}$. Average temperature range of $26.9-28^{\circ} \mathrm{C}$ has however been reported for Otamiri river in previous studies $[5,18]$. Temperature is known to affect the dissolved oxygen level in aquatic ecosystem, which in turn has deleterious effects on various aquatic biotas therein. The high phosphate recorded in Otamiri sediment in this study could be traced to the use of phosphate fertilizers for urban agriculture and industrial sources. Such high levels of phosphates could lead to excessive proliferation of algae (algal bloom), with its attendant consequences on dissolved oxygen level in the river. However, this high level of phosphate in the sediment was not replicated in the river water $(0.032 \mathrm{Mg} / \mathrm{l})$. Such low levels of phosphates have been reported for the river by previous authors $[18,5]$. Similarly, phosphate range of $0.8-5.6 \mathrm{mg} / \mathrm{l}$, which is above the WHO recommended standard for drinking water, has been reported for Otamiri [20].

The BOD was of the same value as the World Health Organization recommended standard while Dissolved oxygen (DO) recorded in this study was just slightly below the WHO recommended standard for drinking water. The relatively low levels of BOD and DO in the present study is surprising, as dumping of both biodegradable and non-biodegradable wastes in Otamiri river banks is been reported to gradually becoming a norm rather than an exception [21]. Okoro et al. [18] has reported BOD range 0.2 to $0.6 \mathrm{mg} / 1$ for Otamiri river water. However, BOD and DO ranges of 11.3 to 15.67 and 8.45 to $12.85 \mathrm{mg} / \mathrm{l}$ respectively have also been reported for the river water by previous authors [22, 17]. The high turbidity recorded in this study relative to the WHO recommended standard for drinking water could be attributed to run-offs from adjoining farm lands at the banks of the river, prolonged human activities in the river as well as increasing sand mining or dredging going on in the river [21]. Similarly, the high levels of electrical conductivity observed in the study could be due to the high content of major ions in Otamiri river, as reported by elsewhere [18, $20]$. 
Heavy metals in waters and sediment could result from the weathering of parent rocks or anthropogenic activities. In recent past, so many studies have been undertaken on the heavy metals contents of Otamiri river and sediment $[19,17$, 20-23]. Some of these studies showed that there has been a progressive accumulation of heavy metals in Otamiri sediment and by extension the river as result of industrial, agricultural or domestic activities. Among the heavy metals studied, lead, cadmium, nickel and mercury contents of Otamiri river were above the WHO recommended standards for drinking water. Generally, the high levels of these heavy metals in the river could be attributed to the indiscriminate dumping and subsequent burning of such solid wastes at the river bank, activities at auto-mechanic workshops at Nekede mechanic village, run-offs from Owerri urban and environs, unrestricted discharging of untreated industrial and domestic effluent into the river. In addition, the slight acidic $\mathrm{pH}$ recorded in the river might have also contributed to the high levels of some of these metals, as low $\mathrm{pH}$ has been shown to enhance the release of heavy metals from polluted sediment [24].

The heavy metals content of Otamiri sediment was higher than those of the river water. This could be attributed to the accumulative nature of heavy metals in the sediment. According to Hanson et al. [25], metals can bind to the organics and inorganics in the water and eventually settle at the bottom of streams, rivers, reservoirs, lakes, estuaries or marine waters. Thus, metal concentrations in sediments are generally much higher than the concentrations in the overlying water [26]. In addition, the occurrence of higher amount of some of the heavy metals in the river water as against the sediment could be due to the physical disturbances, such as sand dredging/mining going-on in the river. In Otamiri river water, iron, zinc, mercury, lead and nickel recorded values higher than the WHO recommended standards for drinking water. The 0.066 and $1.054 \mathrm{mg} / \mathrm{L}$ concentrations of nickel observed for Otamiri river water and sediment respectively in the present study were higher than the concentration range of between 0.005 and $0.010 \mathrm{mg} / \mathrm{L}$ of dissolved nickel generally reported in aquatic ecosystems [27]. The toxic effect of nickel to aquatic organisms has been shown to vary significantly according to species of organisms, as well as water hardness and $\mathrm{pH}[28,29]$. Elevated concentrations of nickel could cause sub lethal effects though its toxicity is generally low [30]. The relatively high level of iron over other heavy metals in both river water and sediment could be attributed to the high levels of iron in the upper earth crust of southern Nigeria [19]. The absence of cobalt and reduced levels of some of the heavy metals in the river water could be attributed to their inability to remain in solution. Nweke et al. [31] made similar observation in New Calabar river. These observations are in agreement with the previous report that in an undisturbed aquatic environment, metals are preferentially transferred from the river water phase to the sediment and thus the concentrations of heavy metals in aquatic environment, are generally much higher in sediment than in the overlying water [26].
In Nigeria, reports on surfactants content of surface waters are very scarce and Otamiri river is not an exception. Perfluoroalkyl and polyfluoroalkyl substances (PFAS) have been reported to be common in both fresh and salt waters, sediments, soil and tissues of wildlife and humans [32-35]. In the present study, perfluorobutanesulfate (PFBS) was not detected in Otamiri river. Although at present, both perfluorinated surfactants and their precursors are neither regulated in surface waters nor drinking water or organic waste materials, Skutlarek et al. [36] recorded perfluorobutanesulfate ranges of $0-46 \mathrm{ng} / \mathrm{L}, 0-1450 \mathrm{ng} / \mathrm{L}$ and 0-71ng/L respectively for Rhine, Moehne and Ruhr rivers and their selected tributaries, in their study on perfluorinated surfactants in surface and drinking water. Similarly, Saito et al. [37] recorded lowest limits of detection of 0.06 and 0.04 $\mathrm{ng} / \mathrm{L}$ for perfluorooctanoate and perfluorooctane sulfonate respectively, in their study on the concentrations of those compounds in surface water in Japan. The non detection of PFBS in Otamiri river could probably be attributed to its concentration being below the detectable limit of the equipment used or the method applied. Otamiri sediment however recorded $0.0142 \mathrm{mg} / \mathrm{kg}$ of PFBS. Sediment has been reported to have a large impact on the distribution, transportation, and fate of persistent organic pollutants in aquatic environment, since it serves as an important sink and reservoir of these compounds [38, 39]. The distribution of polyfluoroalkyl substances (PFAS) between water and sediment is considered a vital process that is known to control their mobility and fate [40, 41]. Sediment-water partitioning is a complex process, that depends both on the physicochemical properties of the compounds and the nature of the sediment, such as the organic matter content [42-45]. The slightly acidic $\mathrm{pH}$ of Otamiri river as observed in the present study (5.40) may have also contributed to the detection of PFBS in Otamiri sediment but not in the river water. Laboratory studies have shown adsorption of PFAS to progressively increase with decrease in $\mathrm{pH}$ of the water and increasing organic matter contents of sediments [43].

Ammonium lauryl sulfate was one of the anionic surfactants detected in both Otamiri river and sediment at $0.070 \mathrm{mg} / \mathrm{l}$ and $0.0303 \mathrm{mg} / \mathrm{kg}$ respectively. Their level of distribution in water and sediment in this study could be due to its high solubility. Ammonium lauryl sulfate on its own may be non-toxic, it is however a nitrosating agent, which on decomposition and or reaction can cause nitrosamine contamination. Once inside the body, nitrosamines can be activated by cytochrome P-140 enzymes, and can therefore induce their carcinogenic effects by forming DNA adducts at the N-and O-atoms [46, 47].

Sodium methyl sulfate was detected both in Otamiri river water and sediment. The proportion found in the river water $(0.060 \mathrm{mg} / \mathrm{l})$ was slightly higher than in the sediment $(0.0532$ $\mathrm{mg} / \mathrm{l})$. This could be attributed to its high solubility. In addition, anionic surfactants are known to form foam; such stable foam formation in the river could be detrimental to the survival of many aquatic organisms by blocking the transformation of the oxygen-mass from air to water. 
Furthermore, hydrophilic constituents of toxic surfactants can endanger the lives of aquatic animals and bacteria in water [48].

Sodium dodecyl sulfate (SDS) is not presently regulated in water systems or listed as a ground water contaminant [49]. SDS was relatively high in Otamiri river water $(0.10 \mathrm{mg} / \mathrm{l})$ and sediment $(0.4531 \mathrm{mg} / \mathrm{l})$. In this study, both the river water and sediment had concentrations of SDS higher than the permissible limit $(0.02 \mathrm{mg} / \mathrm{l})$ for anionic surfactant in class I water [50]. Similarly, the sediment also recorded SDS concentration higher than the non-effect concentration value $(0.25 \mathrm{mg} / \mathrm{l})$ for surfactants as reported by van de Plassche et al [51]. In addition, anionic LAS have been reported to be preferentially adsorbed to sediments [52]. Similarly, in a study on aquatic environmental monitoring and removal efficiency of detergents, LAS variations between surface and bottom waters were reported [53]. In addition, surfactant concentrations in surface waters as high as $0.416 \mathrm{mg} / \mathrm{l}$ has been recorded in the United Kingdom [54]. In Massachusetts, the Town River had reported concentrations between 0.04 and $0.590 \mathrm{mg} / \mathrm{l}$, while other major rivers in the United States had reported 0.01 to $3.30 \mathrm{mg} / 1$ or 0.01 to $0.04 \mathrm{mg} / 1$ [55-57]. Nevertheless, these levels of SDS in Otamiri river and sediment could pose a great danger to aquatic lives in the river. The anionic surfactant Sodium laureth sulfate was also detected in the river and sediment. Though ecotoxicity studies by Abel [58], have demonstrated that a surfactant concentration of $0.5 \mathrm{mg} / \mathrm{l}$ in natural water may not be substantially toxic to fish and other aquatic life under most conditions, chronic toxicity of anionic surfactants has however been shown to occur at concentrations as low as 0.1 $\mathrm{mg} / \mathrm{l}$ [59]. Furthermore, surfactants have been reported to combine with heavy metal ions thus enhancing the toxicity of heavy metals to fishes and other aquatic organisms [60, 61].

The higher concentration of most of these anionic surfactants in the river phase compared to the sediment fraction in this study could be attributed to the continuous sand dredging going-on in the river, as it has been previously reported that physical disturbances could cause the redistribution of the sediment-associated contaminants in the water phase to disturb the activities of suspended microorganisms [62]. Generally, the presence of these anionic surfactants in Otamiri river and sediment might be attributed to unrestricted discharge of untreated domestic sewage from Owerri urban and environs, laundry and car washing outfits located at the bank of the river among others.

The bacteria isolated from Otamiri river include: Serratia marcescens (SerEW01), Staphylococcus, Streptococcus, Enterococcus and Escherichia coli. In the sediment however, Streptococcus, Pseudomonas, Klebsiella, Acinetobacter seifertii, Bacillus and Escherichia coli were isolated. These isolates have been reported by previous authors that have worked in the river and its sediment [63-65]. Among the isolates from the river, Serratia marcescens (SerEW01) recorded the highest percentage occurrence of $33.33 \%$, followed by Staphylococcus and Streptococcus species $(22.2 \%)$. These are opportunistic pathogens of human origin.
Serratia marcescens (SerEW01) is known to cause hospitalacquired infections, particularly catheter-associated bacteriaemia, urinary and respiratory tract, as well as wound infections [64]. The presence of Streptococci and Escherichia coli was an indication of the poor sanitary quality of the Otamiri river [66]. World Health Organization recommended one E. coli cell per $100 \mathrm{ml}$ of water sample to be normal [68]. However, these indicator organisms, as well as Klebsiella species were found in large numbers in Otamiri river and sediment, indicating possible feacal contamination. In the Otamiri sediment, Pseudomonas and Bacillus were fairly prevalent. This could be attributed to their wide spread in water and soil ecosystems as reported by Rogers et al. [69]. Acinetobacter seifertii recorded the highest percentage occurrence of $42.10 \%$ in Otamiri sediment. The presence of hospitals and other medical facilities at the bank of at the bank of Nworie river (a tributary of Otamiri) may have contributed to the high percentage occurrences of some of these human pathogens in the river and its sediment. In addition, some anionic surfactants were prevalent in the river water and sediment as shown in Table 1, the presence of such substrates can stimulate the proliferation of such organisms that can utilize them as carbon and energy sources. Some of these isolates have been reported to degrade anionic surfactants and other detergents [61, 70-72].

\section{Conclusion}

In the present study, the bacteriological, physicochemical and anionic surfactants qualities of Otamiri river and sediment were evaluated. The results showed the presence of some indicator bacteria in both river water and sediment, suggesting the possibility of fecal contamination of Otamiri river. Similarly, $\mathrm{Pb}$, $\mathrm{Cd}, \mathrm{Ni}, \mathrm{Hg}$, electrical conductivity and turbidity had values higher than WHO recommended quality standards for drinking water. Among the anionic surfactants detected in the aquatic ecosystems, sodium dodecyl sulfate (SDS) was found to record high values in both the river and sediment. These show that the water quality of Otamiri river and sediment has deteriorated over time. It is therefore recommended that this study should be extended to include cationic and non-ionic surfactants in Otamiri river and sediment.

\section{References}

[1] Arora, K. R. (2007). Irrigation, Water power and Water Resources Engineering. $4^{\text {th }}$ edn., Delhi: Standard Publishers Distributors.

[2] Gupta, B. L and Gupta, A. (2008). Water Resources Systems and Management, $2^{\text {nd }}$ edn. Delhi: A. K Jain.

[3] Bhatia, S. C. (2009). Environmental Pollution and Control in Chemical Process Industries, New Delhi, Khanna Publishers, pp 164-431.

[4] Symons, J. N., Bradley, L. C and Cleveland, T. C. (2000). The drinking Water Dictionary, New York, McGrawhill Inc. 
[5] Dike, M. U., Nevoh, G. O and Uzoma, H. C. (2016). PhysicChemical and Biological Assessment of River Qualities in Owerri Federal Constituency of Imo State, Nigeria. International Journal of Applied Research, 2 (5): 935-940.

[6] Tebbult, T. H. (1998). Principles of Water Quality Control $5^{\text {th }}$ edn. Oxford, Butterwnth Heinemann.

[7] Onweremadu, E. U. (2007). Soil Mercury Distribution in a Forest-Savanna Mosaic in Relation to Soil Fertility. Research Journal of Environmental Toxicology. 1 (4): 158-166.

[8] Nweke, C. O., Alisi, C. S., Okolo, J. C and Nwanyanwu, C. E. (2007a). Toxicity of Zinc to Heterotrophic Bacteria from aTropical River Sediment. Applied Ecology and Environmental Research, 5 (1): 123-132.

[9] Fawole, M. O and Oso, B. A. (2004). Laboratory Manual of Microbiology. $2^{\text {nd }}$ edn. University Press Plc, Ibadan. 21.

[10] Chessbrough, M (2005). Biochemical Test to Identify Bacteria: District Laboratory Practice in Tropical Countries. $2^{\text {nd }}$ edn. Cambridge University Press, London. 2: 62-70.

[11] Unites States Environmental Protection Agency (1993). Method 365.1, Revision 2.0: Determination of Phosphorus by Semi-Automated Colorimetry. James W. O'Dell ed. US-EPA, Cincinnati, Ohio 45268.

[12] AMERICAN PUBLIC HEALTH ASSOCIATION- APHA: AMERICAN WATER WORKS ASSOCIATION - AWWA; WATER ENVIRONMENT FEDERATION - WEF. Standard methods for examination of water and wastewater. 20th ed. Washington DC, 1998.

[13] Hendershot, W. H., Lalande, H., and Duquette, M. (1993). Soil Reactions and Exchangeable Acidity, In: M. R. Carter, (ed.)- Soil Sampling and Methods of Analysis. Canadian Society of Soil Science, Lewis Publishers, Boca Raton, Florida. pp. 141-142.

[14] Adrian, W. J. (1973). A Comparison of a Wet Pressure Digestion Method with Other Commonly Used Wet and Dry Ashing Method. Analyst, 98: 213-214.

[15] AOAC (1990). Methods of Analysis Using GC-FID. 15 ${ }^{\text {th }}$ edn, Association of Official Analytical Chemists, Arlington, Virginia, USA, 2114-2145.

[16] Anon (2004). Technical Memorandum: pH Requirements of Fresh Water Aquatic Life. Robertson-Bryan Inc., CA, p 1.

[17] Iwuoha, G. N., Osuji, L. C and Onwuachu, U. I. (2013). Impact of Waste Dump on the Sediment and Surface Water Quality of Otamiri River, Nigeria. Journal of Applied Science and Environmental Management, 17 (4): 573-575.

[18] Okoro, B. C., Uzoukwu, R. A and Ademe, C. K (2016). Investigation of Surface Water Quality in Owerri Municipal, Imo State, Nigeria for Human Consumption. ARPN Journal of Engineering and Applied Sciences, 11 (13): 8100-8106.

[19] Iwuoha, G. N., Osuji, L. C and Horsfall, M. Jnr. (2012). Assessment of Pre-Dredging Levels of Heavy Metal Pollution in Sediments of Otamiri River, Imo State of Nigeria. Research Journal of Chemical Sciences, 2 (6): 82-87.

[20] Okeke, P. N and Adinna, E. N. (2013). Water Quality of Otamiri River in Owerri, Nigeria. Universal Journal of Environmental Research and Technology, 3 (6): 641-649.

[21] Temitope, A. E., Ebeniro, L. A., Oyediran, A. G and C-
Oluwatosin, T. J. (2016). An Assessment of Some Heavy Metals in Sediment of Otamiri River, Imo State, SouthEastern Nigeria. Open Access Library Journal, 3: e2462.

[22] Akhionbare, S. M. O. (2011). Factors in the Migration of Heavy Metals in the Otamiri River System. International Journal of Science and Nature. 2 (4): 856-860.

[23] Onyekuru, S. O., Nwankwoala, H. O and Uchechukwu, E. I. (2017). Heavy Metal analysis of Otamiri River in Imo State, Southeastern Nigeria. Journal of Ecology and Natural Resources, 1 (3): 1-6.

[24] Zhang, Y., Zhang, H., Zhang, Z, Liu, C., Sun, C., Zhang, W and Marhaba, T. (2018). pH Effect on Heavy Metal Release from Polluted Sediment. Journal of Chemistry, 2018, 1-7.

[25] Hanson, P. J., Evans, D. W., Colby, D. R and Zdanowicz, V. S. (1993). Assessment of Elemental Contamination in Estuarine and Coastal Environments Based on Geochemical and Statistical Modeling of Sediments. Marine Environmental Research, 36: 237-256.

[26] Bryan, G. W and Langston, W. J. (1992). Bioavailability, Accumulation and Effects of Heavy Metals in Sediments with Special Reference to United Kingdom Estuaries: Environmental Pollution, 76: 89-131.

[27] Galvin, R. M. (1996). Occurrence of Metals in Water: An Overview. Water $S A$, 2: 7-18.

[28] Birge, W. S and Black, J. A. (1980). Aquatic Toxicology of Nickel: In Nickel in the Environment, Nriagu, J. O. (Ed). John Wiley and Sons Inc., USA, 349-366.

[29] Dallas, H. F. and Day, I. A. (1993). The Effect of Water Quality Variables on Riverrine Ecosystems: A Review: Water Research Commission Report No. 351, pp 200.

[30] Khangarot, B. S and Ray, P. K. (1990). Correlation between Heavy Metal, Acute Toxicity Values in Daphnia magna and Fish. Bulletin on Environmental Contamination and Toxicology, 38: 722-726.

[31] Nweke, C. O., Okolo, J. C., Nwanyanwu, C. E and Alisi, C. S. (2006). Response of Plantonic Bacteria of New Calabar River to Zinc Stress. African Journal of Biotechnology, 5 (8): 653-658.

[32] Giesy, J. P and Kannan, K. (2001). Global Distribution of Perflurooctane Sulfonate in Wildlife. Environmental Science and Technology, 35: 1339-1342.

[33] Higgins, C. P., Field, J. A., Criddle, C. S and Luthy, R. G. (2005). Quantitative Determination of Perfluorochemicals in Sediments and Domestic Sludge. Environmental Science and Technology, 39: 13946-13956.

[34] Ahrens, L., Gerwinski, W., Theobald, N and Ebinghaus, R. (2010a). Sources of Polyfluoroalkyl Compounds in the North Sea, Baltic Sea and Norwegian Sea: Evidence from Their Spatial Distribution in Surface water. Marine Pollution Bulletin, 60: 255-260.

[35] Wang, P., Wang, T. Y., Giesy, J. P and Lu, Y. L. (2013). Perfluorinated Compounds in Soils from Liaodong Bay with Concentrated Fluorine Industry Park in China, Chemosphere, 91: 751-757.

[36] Skutlarck, D., Exner, M and Farber, H (2006). Perfluorinated Surfactants in Surface and Drinking Waters. Environmental Science and Pollution Res, 13 (5): 299-307. 
[37] Saito, N., Harad, K., Inoue, K., Sasaki, K., Yoshinaga, T and Koizumi, A. (2004). Perfluorooctanoate and Perfluorooctane Sulfonate Concentrations in Surface Water in Japan. Journal of Occupational Health, 46: 49-59.

[38] Ahrens, L., Yamashita, N., Yeung, L. W. Y., Taniyasu, S., Horii, Y., Lam, P. K. S and Ebinghaus, R. (2009). Partitioning Behaviour of Per- and Polyfluoroalkyl Compounds Between Pore Water and Sediment in Two Sediment Areas from Tokyo Bay, Japan. Environmental Science and Technology, 69696975.

[39] Yang, L. P., Zhu, L. Y and Liu, Z. Y. (2011). Occurrence and Partition of Perfluorinated Compounds in Water and Sediment from Liao River and Taihu Lake, China. Chemosphere, 83: 806-814.

[40] Prevedouros, K., Cousins, I. T., Buck, R. C and Korzeniowski, S. H. (2006). Sources, Fate and Transport of Perfluorocarboxylates, Environmental Science and Technology, 40: 32-44.

[41] You, C., Jia, C. X and Pen, G. (2010). Effect of Salinity and Sediment Characteristics on the Sorption and Desorption of Perfluorooctane Sulfonate at Sediment-Water Interface. Environmental Pollution, 158: 1343-1347.

[42] Liu, J. X. and Lee, L. S. (2005). Solubility and Sorption by Soils of 8: 2 Fluorotelomer Alcohol in Water and Cosolvent Systems. Environmental Science and Technology, 39: 75357540 .

[43] Higgins, C. P and Luthy, R. G. (2006). Sorption of Perfluorinated Surfactants on Sediments. Environmental Science and Technology, 40: 7251-7256.

[44] Ahrens, L., Taniyasu, S., Yeung, L. W. Y., Yamashita, N., Lam, P. K. S and Ebinghaus, R. (2010b). Distribution of Polyfluoroalkyl Compounds in Water, Suspended Particulate Matter and Sediment from Tokyo Bay, Japan. Chemosphere, 79: $266-272$.

[45] Zhao, L. X., Zhu, L. Y., Yang, L. P., Liu, Z. T and Zhang, Y. H. (2012). Distribution and Description of Perfluorinated Compounds in Fractionated Sediments. Chemoshere, 88: 1390-1397.

[46] Oyama, T., Sugio, K., Uramoto, H., Iwata, T., Onitsuka, T., Isse, T., Nozoe, T., Kagawa, N., Yasumoto, K. and Kawamoto, T. (2007). Increased Cytochrome P450 and Aryl Hydrocarbon Receptor in Bronchial Epithelium of Heavy Smokers with Non-Small Cell Lung Carcinoma Carries a Poor Prognosis. Front Biosciences, 12: 4497-4503.

[47] Sasaki, S., Sata, F., Katoh, S., Saijo, Y., Nakajima, S., Washino, N., Konishi, K., Ban, S., Ishizuka, M and Kishi, R. (2008). Adverse Birth Outcomes Associated with Maternal Smoking and Polymorphisms in the N-NitrosamineMetabolizing Enzyme Genes NQO1 and CYP2E1. American Journal of Epidemiology, 167 (6): 719-726.

[48] Effendi, I., Nedi, S., Feliatra, F and Pakpahan, R. (2017). Detergent Disposal into Our Environment and Its Impact on Marine Microbes. Earth and Environmental Science, 97: 1-9.

[49] Kegley, S. E., Hill, B. R., Ome, S and Choi, A. H. (2014). PAN Pesticide Database. Pesticide Action Network, North America. Oakland, CA. Available at http:www.pesticideinfo.org.

[50] Pastewski, S and Medrzycka, K. (2003). Monitoring
Surfactant Concentrations in Surface Waters in Tricity Agglomeration. Polish Journal of Environmental Studies, 12 (5): 643-646.

[51] Van de Plassche, E. J., de Bruijn, J. H. M., Stephenson, R. R., S. J. Marshall, S. J., Feijtel, T. C. J and Belanger, S. E. (1999). Predicted No Effect Concentrations and Risk Characterization of Four Surfactants: Linear alkyl Benzene Sulfonate, Alcohol Ethoxylates, Alcohol Ethoxylated Sulfates, and Soap. Environmental Toxicology and Chemistry, 18: 2653-266.

[52] Sanderson, H., Dyer, S. D., Price, B. B., Nielson, A. M., Van Compernolle, R., Selby, M., Stanton, K., Evans, A., Ciarlo, M and Sedlak, R. (2006). Occurene and Weight- of- Evidence Risk Assessment of Alkyl Sulfates, Alkyl Ethoxysulfates and Linear Alkylbenzene Sulfonates (LAS) in River Water and Sediments. Science and Total Environment, 368: 659-712.

[53] Abd El-Gawad, H. S. (2014). Aquatic Environmental Monitoring and Removal Efficiency of Detergents. Water Science, 28: 51-64.

[54] Fox, K., Holt, M., Daniel, M., Buckland, H and Guymer, I. (2000). Removal of Linear Alkylbenzene Sulphonate from a Small Yorkshire Stream: Contribution to Greater project No 7. Science of the Total Environment. 251/252: 265-75.

[55] Lewis, M. A and Wee, V. T. (1983). Aquatic Safety Assessment for Cationic Surfactants. Environmental Toxicology and Chemistry 2: 105-118.

[56] A. D. Little Co. (1981). Human Safety and Environmental Aspect of Major Surfactants (Supplement). Report to the Soap and Detergent Association. ADL Reference 84048.

[57] Hennes, E. C., and Rapaport, R. A. (1989). Calculation and Analytical Verification of Linear Alkylbenzene Sulfonate Concentrations in Surface Waters, Sediment and Soil. Tenside Surfactants Detergents 26: 141-147.

[58] Abel, P. D. (1974). Toxicity of Synthetic Detergents to Fish and Aquatic Invertebrates. Journal of Fishery Biology, 6: 279-298.

[59] Lewis, M. A. (1991). Chronic and Sub Lethal Toxicities of Surfactants to Aquatic Animals: A Review and Risk Assessment. Water Research 25 (1): 101-113.

[60] Swedmark, M., Granmo, A and Bjorck, E. (1978). Effects of Surfactants on the Toxicity of Heavy Metals to Marine Animals. Research Report to the National Swedish Environment Protection Board. 1-122.

[61] Karbe, (1975). Toxicity of Heavy Metals Modified by Environmental Stress. International Conference on Heavy Metals in the Environment. Toronto, Ontario, Canada. Document C-14.

[62] Nweke, C. O and Orji, J. C. (2009). Toxicity of Heavy Metals to Microbial Community of New Calabar River. Nigerian Journal of Biochemistry and Molecular Biology, 24 (1): 48-54.

[63] Ogbulie, T., Ogbulie, J. A. N. and Uwazuruike, I. (2010). Biodegradation of Detergents by Aquatic Bacterial Flora from Otamiri River, Nigeria. African Journal of Biotechnology, 7 (6): 824-830.

[64] Oga, J. O., Ogah, R. O and Ubaka, K. G. (2018). Bacteriological Assessment of Water from Otamiri River in Owerri Imo State. International Journal of Chemistry and Chemical Processes, 4 (2): 2545-5265. 
[65] Fagorite, V., Cosmos, A., Ibeneme, I., Ekeoma, C., Ukwajiuno, J., Abiahu, C and Poopola, J. (2019). Microbial Assay of Otamiri River and its Sediment in Parts of Owerri. Journal of Geoscience and Environment Protection. 7: 155166.

[66] Greenwood, D., Slack, R. C. B and Peutherer, J. F. (eds) (1992). Medical Microbiology $14^{\text {th }}$ edn. Longman Group, London. 340.

[67] Ibeneme, S. I., Ofulume, A. B., Okechi, R. N., Haruna, I. V., Ukiwe, L. N., Udensi, J. U., Nwachukwu, J. C and Adora, H. U. (2014). Assessment of the Quality of Water Resources of Ahaba and Ovim Areas, Iukwato Southeastern Nigeria. International Journal of Current Microbiology and Applied Sciences, 3 (1): 181-193.

[68] World Health Organization (WHO) (2006). Guidelines for Drinking Water. First Addendum to the $1^{\text {st }}$ edn., vol. 1, recommendations, Geneva, 595.
[69] Roggers, Y. S., Edavid, A. A and John, L. I (1977). General Microbiology, $4^{\text {th }}$ edn. MacMillan Publishers Ltd, London. 595-596.

[70] Anaukwu, C. G., Ezemba, C. C., Anakwenze, V. N., Agu, K. C., Nwankwegu, A. S., Okeke, B. C and Awah, N. S. (2016). Influence of Anionic, Cationic and Non-Ionic Surfactants on Growth of Hydrocarbon Utilizing Bacteria. American Journal of Current Microbiology. 4 (1): 10-16.

[71] Abimbola, O, A and Iyanuoluwa, U. (2017). Biodegradation of SodiuDodecylsulphate (SDS) by Two Bacteria Isolated from Wastewater Generated by a Detergent Manufacturing Plant in Nigeria. Jordan Journal of Biological Sciences, 10 (4): 251-255.

[72] Abimbola, O, A., Wasiu, O. O and Adedolapo, V. O. (2018). Degradation of Surfactant and Metal-Removal by Bacteria from a Nigerian Laundry Environment. European Journal of Biological Research, 8 (4): 243-251. 